Seyahat ve Otel İşletmeciliği Dergisi/

Journal of Travel and Hospitality Management

14 (2), 2017, 65-79.

Gönderim Tarihi:28.04.2016

Kabul Tarihi:29.08.2016

\title{
Restoranlarda Bahşiş İle İlgili Yayınlanan Makalelerin Bibliyometrik Analizi
}

\section{Bibliometrics Analysis of Published Papers on Tipping in Restaurants}

\author{
Arş. Gör. Gökhan YILMAZ \\ Akdeniz Üniversitesi \\ Turizm Fakültesi \\ E-posta: gokhanyilmaz@akdeniz.edu.tr \\ Orcid Id:0000-0002-8254-8955
}

Öz

Çalışmada, 1978-2015 yılları arasında restoranlarda bahşiş ile ilgili uluslararası alanyazında yayınlanan makalelerin belirli parametreler çerçevesinde incelenmesi amaçlanmaktadır. Bu doğrultuda çeşitli veri tabanları üzerinden erişim sağlanan 201 makale değerlendirmeye alınmıştır. Özellikle veri tabanları üzerinden tarama esnasında tip, tipping, tipping behavior, gratuity gibi anahtar kelimeler kullanılmıştır. Bu bağlamda restoranlarda bahşiş ile ilgili en fazla makalenin 2004-2015 yılları arasında yayınlandığı, görgül çalışmaların ağırlıklı olduğu, tek yazarlı makalelerin daha fazla yayınlandığı, bahşiş arttırma teknikleri ile ilgili yapılan çalışmaların sayısının daha yüksek olduğu ve çalışmaların 6-10 sayfa arasında olduğu sonucuna ulaşılmıştır. Makalelerin çoğunluğunda anket tekniğiyle verilerin toplandığı, örneklem grubunu müşterilerin oluşturduğu ve genellikle makalelere atıf yapıldığı dikkat çekmektedir. Makalelere en fazla katkı yapan akademisyenlerin Cornell Üniversitesi'nde çalıştığı ve en fazla çalışmanın Michael Lynn tarafından yapıldığı tespit edilmiştir. Tüm bunların ışığında bu çalışmadan elde edilen bulgular bahşiş ile ilgili çalışmaların sayısının giderek arttığını ve işletme, pazarlama, ekonomi, sosyoloji, psikoloji, turizm araştırmacıların bahşiş ile ilgili çalışmalara daha fazla ilgi gösterdiğini göstermektedir.

Anahtar Kelimeler: Restoran, bahşiş, bahşiş davranışı, bibliyometrik analiz

\begin{abstract}
The aim of this research was to examine the papers on tipping in restaurants found in international literature in period from 1978 to 2015 based on defined parameters ofbibliometrics analysis. 201 article from various database were included in the research. In database search keywors like tip, tipping, tipping behavior, gratuity were used. Based on the results of the analysis it can be concluded that: the most paper were published between 2004 and 2015; the emphasis was more on empirical studies; the papers were written by one author; more papers aimed of defining tipping increase techniques and average length of papers was 6 to 10. While most frequently used data collection method was survey, sample group was largely consisting of customers, and research papers were being used as reference. The authors who made the largest contribution to literature were from Cornell University and Michael Lynn was extracted as author of most papers. Based on results of this research overall evaluations of literature on tipping in restaurants were presented.
\end{abstract}

Keywords: Restaurant, tipping, tipping behavior, bibliometrics analysis 


\section{Giriş}

Bibliyometri, özünde sayım yapmaya dayalı bir inceleme alanı olarak belirtilmektedir (Al ve Coştur, 2007). Bibliyometri kavramı, yayınlanmış kitap, dergi, makale gibi bilimsel bilgi paylaşım araçlarının matematiksel ve istatistiksel tekniklerle incelenmesi (Pritchard, 1969; Diodato, 1994; Evren ve Kozak, 2012) olarak tanımlanmaktadır. Bibliyometrik analiz ise belgelerin ya da yayınların yazar sayısı, yayınlandığı dergi, konu, yayın bilgisi gibi belirli özelliklerinin niceliksel olarak analiz edilmesi (Al ve Tonta, 2004; Yalçın, 2010; Ulu ve Akdağ, 2015) şeklinde açıklanmaktadır. Bibliyometrik araştırmalar, belgelerin ya da yayınların belirli özelliklerinin analiz edilmesi ve bilimsel iletişime ilişkin çeşitli bulguların elde edilmesi esasına dayanmaktadır (Al ve Coştur, 2007).

Bir bilim dalı ile ilgili yapılan çalışmaların nicelik ve nitelik açısından gelişimi ilgili bilim dalının performansının değerlendirilmesinde önemli bir rol oynamaktadır (Law ve Cheung, 2008). Bu bağlamda bibliyometri araştırmaları, bilimsel çalışmaların gerek nicelik gerekse nitelik açısından değerlendirmesine imkan sağlamaktadır (Al ve Soydal, 2012). Benzer bir şekilde bibliyometri araştırmaları ilgili bilim dalına o alanda çalışan bilim insanlarının katkılarının belirlenmesi, akademik dergilerin niteliklerinin belirlenmesi veya diğer bilim dalları ile ilişkisinin tespit edilmesine de katkı sağlamaktadır (Üstdiken ve Pasadeos, 1992; Yozgat ve Kartaltepe, 2009). Diğer taraftan bir bilim dalı ile ilgili alanyazının, dergilerin veya çalışmaların belirli dönemlerde incelenmesi gerek bilimsel çalışmaların gelişimlerinin ortaya konulması gerekse bu alanda bilgi sahibi olunması açısından önem arz etmektedir (Kozak, 1994; 2001; 2003). Bibliyometrik çalışmalar sonucunda elde edilen bulgular ilgili bilim dalının nasıl gelişim gösterdiğinin tespit edilmesine, sorunların veya eksikliklerin ortaya çıkarılmasına ve bu bağlamda yapılacak düzeltmelerin ya da getirilecek önerilerin tartışılmasına da imkan sağlamaktadır (Üstdiken ve Pasadeos, 1993; Şakar ve Cerit, 2013; Ulu ve Akdağ, 2015). Genellikle bibliyometrik çalışmaların turizm genelinde yoğunlaştığı ve gastronomi ya da yiyecek ve içecek alanında ise özellikle son yıllarda bu tür çalışmaların yapılmaya başlandığı görülmektedir. Bu bağlamda ulusal ve uluslararası yazın incelendiğinde restoranlar özelinde yapılmış herhangi bir bibliyometrik çalışmaya rastlanılmamıştır. Diğer taraftan restoranlarda bahşiş ile ilgili Türk araştırmacılar tarafından yapılan gerek ulusal yazında (Devrani, 2014a; 2014b) gerekse uluslararası yazında (Artuğer ve Çetinsöz, 2013; Doğan ve Özaslan, 2013; Yeşiltaş vd., 2014; Özdemir vd., 2014) yok denecek kadar az sayıda çalışmanın olduğu da dikkat çekmektedir. Tüm bunların ışığında ulusal yazında bibliyometri çalışmalarının turizm ve turizm ile ilgili konular çerçevesinde yapıldığı göz önüne alındığında bu çalışmanın hem ilgili yazına katkı sağlayacağı hem de bu alanda çalışan araştırmacılara yol göstereceği düşünülmektedir. Ayrıca bu çalışmada ulusal yazında yer alan çalışmalarda kullanılan parametrelerin yanı sıra farklı parametrelerin (makalenin veri toplama araçları, makalenin örneklem grubu, makalede verilerin toplandığı ülke ve şehir gibi) kullanılmasının da bir farklılık yaratacağı varsayılmaktadır. Bu bağlamda bu çalışmada 1978-2015 yılları arasında restoranlarda bahşiş ile ilgili uluslararası alanyazında yayınlanmış makalelerin belirli parametreler çerçevesinde incelenmesi amaçlanmaktadır.

\section{Kavramsal Çerçeve}

Dünya genelinde bilimsel yayınların analiz edilmesi ile ilgili yapılan çalışmaların giderek artış gösterdiği görülmektedir (Kozak, 1994; Webster ve Watson, 2002). Turizmin bir bilim dalı olarak ortaya çıkması ve bu alanda yayın yapan akademisyen sayısının artması, bibliyometrik çalışmaların turizm alanında da tercih edilmesine neden 
olmaktadır (Hall, 2011). Bu bağlamda uluslararası alanyazında turizm alanında yayınlanan çok sayıda bibliyometrik çalışmanın (Jogaratnam vd. 2005; McKercher, 2007; Huang ve Hsu, 2008; Ma ve Law, 2009) olduğu dikkat çekmektedir. Söz gelimi Jogaratnam vd. (2005) tarafından yapılan çalışmada turizm alanında önde gelen 11 dergide 1992-2001 yılları arasında yayınlanan makaleler yazarların çalıştığı üniversite, katkı yapan bölgeler ve yazarların en fazla tekrar yayın yaptıkları dergiler çerçevesinde değerlendirmektedir. Benzer bir şekilde McKercher (2007) da turizm alanında önde gelen 25 dergide 2000-2004 yılları arasında yayınlanan 3153 makaleyi yazar profili ve yayın profili olmak üzere iki açından incelemektedir. Huang ve Hsu (2008) ise Çin'de önde gelen turizm dergilerinde 2000-2005 yılları arasında yayınlanan 500 makaleyi araştırma konuları, araştırma yöntemleri, yazar bilgisi gibi çeşitli değişkenler açısından değerlendirmektedir. Ma ve Law (2009) da Annals of Tourism Research dergisinde 1973-2006 yılları arasında yayınlanan 1034 makaleyi çeşitli bibliyometrik parametreler doğrultusunda incelemektedir. Gastronomi veya yiyecek içecek alanında yapılan çalışmalara bakıldığında ise bibliyometrik çalışmaların sayısının daha az olduğu dikkat çekmektedir. Söz gelimi Sanchez ve arkadaşları (2016) tarafından yapılan araştırmada şarap turizmi ile ilgili 1984-2014 yılları arasında yayınlanan 166 makalenin bibliyometrik profili ortaya konulmaktadır. Bu bağlamda uluslararası yazında gerek turizm gerekse gastronomi alanında yapılan bibliyometrik çalışmalara verilen örnekleri arttırmak mümkündür.

Ulusal yazında turizm ile ilgili yapılan bibliyometrik çalışmaların ise 1990'ı yılların ortalarında başladığı görülmektedir. Bu bağlamda alanyazında yer alan bibliyometrik çalışmalarda araştırmacıların genellikle makaleleri (Kozak, 1994; 1995; İçöz ve Kozak, 1999; Evren ve Kozak, 2012; Özel ve Kozak, 2012; Temizkan vd., 2015), lisansüstü tezleri (Kozak, 2001; Cevizkaya vd., 2014), dergileri (Kozak, 1999; Özdemir ve Kozak, 2000) ve bildirileri (Çakıcı vd., 2013) incelediği dikkat çekmektedir. Ulusal yazında turizm ile ilgili yayınlanan bibliyometrik çalışmalar ve bu çalışmalarda kullanılan parametreler Tablo 1'de gösterilmektedir. Turizm ile ilgili bibliyometrik çalışmalar incelendiğinde zaman içerisinde araştırmacıların kullandığı parametrelerin sayısında artış olduğu dikkat çekmektedir. Söz gelimi, Kozak (1994) Anatolia: Turizm Araştırmaları Dergisi'nde 1990-1994 yılları arasında yayınlanan makaleleri yazarın unvanı, çalışmanın konusu, yayınlandığı yıl, sayfa sayısı, yazarın çalıştığı üniversite, çalışmanın görgül veya kavramsal olup olmadığı, yazar sayısı ve çalışmanın çeviri olup olmadığı gibi parametreler çerçevesinde incelemektedir. Bu bağlamda en fazla makalenin turizm pazarlaması alanında yayınlandığı, en fazla katkının Anadolu Üniversitesi'nde çalışan akademisyenler tarafından sunulduğu, çalışmalarının çoğunluğunun kavramsal, tek yazarlı ve 2-5 sayfa aralığında olduğu sonucuna ulaşmıştır. Kozak (1995) da Türkiye'de 1979-1994 yılları arasında turizm ile ilgili yayınlanan makaleleri incelemekte ve en fazla makalenin Turizm Yıllığı'nda yayınlandığını belirtmektedir. Ayrıca çoğunlukla makalelerin 1990-1994 yılları arasında, konaklama işletmeciliği konularında, kavramsal yaklaşımla ve sektör temsilcileri ile öğrenciler tarafından yayınlandığı sonucuna ulaşmıştır. Benzer bir şekilde Çiçek ve Kozak (2012a) Anatolia Turizm Araştırmaları Dergisi'nde 1997-2011 yılları arasında yayınlanan makaleleri değerlendirmektedir. Bu çerçevede 1997-2001 yılları arasında daha fazla makale yayınlandığı, ağırlıklı olarak ampirik çalışmaların bulunduğu, Anadolu Üniversitesi'nde çalışan akademisyenlerin daha fazla katkı sağladığı ve çoğunlukla yabancı kaynaklara atıf yapıldığı sonucuna varmıştır. Zencir ve Kozak (2012) Sosyal Bilimler Enstitü dergilerinde 2000-2010 yılları arasında yayınlanan turizm ile ilgili 206 makaleyi benzer parametrelerle incelemektedir. İki yazarlı makalelerin sayısının diğerlerine oranla fazla olduğu, en fazla yayının turizm yönetimi konularında yapıldığı, çoğunlukla görgül araştırmaların kullanıldığı, yabancı kaynak kullanımın yüksek olduğu ve en fazla çalışmanın 2008 yılında yapıldığı tespit edilmiştir. 
Tablo 1: Ulusal Alanyazında Turizm ile ilgili Yayınlanan Bibliyometrik Çalışmalar

\begin{tabular}{|c|c|c|c|c|c|c|c|c|c|c|c|c|c|c|c|c|c|c|c|c|c|c|c|c|}
\hline \multirow[b]{3}{*}{ Çalışma } & \multirow[b]{3}{*}{$\begin{array}{l}\text { İncelenen } \\
\text { Yillar }\end{array}$} & \multirow[b]{3}{*}{ İncelenen Konu } & \multirow[b]{3}{*}{$\begin{array}{l}\text { İncelenen } \\
\text { Çalışma } \\
\text { Sayısı }\end{array}$} & \multicolumn{21}{|c|}{ Çalışmada Kullanılan Parametreler } \\
\hline & & & & \multicolumn{16}{|c|}{ Makale / Bildiri / Tez ile ilgili } & \multicolumn{5}{|c|}{ Yazar ile ilgili } \\
\hline & & & & 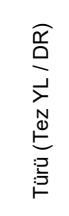 & 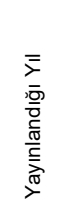 & 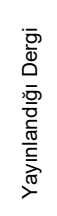 & 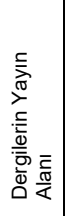 & 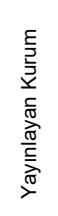 & 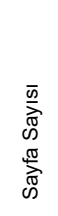 & 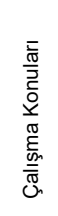 & 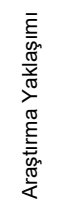 & 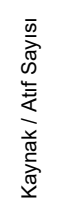 & 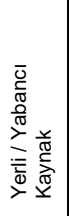 & 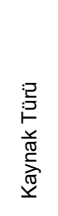 & 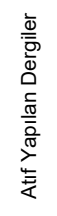 & 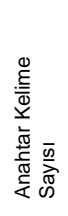 & 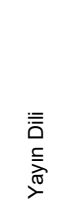 & 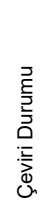 & 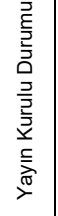 & 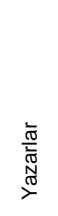 & 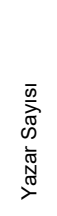 & 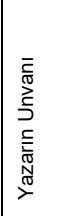 & 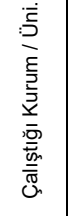 & 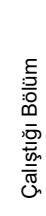 \\
\hline Kozak (1994) & 1990-1994 & $\begin{array}{l}\text { Anatolia Dergisi'nde yayınlanan } \\
\text { makaleler }\end{array}$ & 249 makale & & $\checkmark$ & & & & $\checkmark$ & $\checkmark$ & $\checkmark$ & & & & & & & $\checkmark$ & & & $\checkmark$ & $\checkmark$ & $\checkmark$ & \\
\hline Kozak (1995) & 1979-1994 & $\begin{array}{l}\text { Türkiye'de turizm ile ilgili } \\
\text { yayınlanan makaleler }\end{array}$ & 491 makale & & $\checkmark$ & $\checkmark$ & & & & $\checkmark$ & $\checkmark$ & & & & & & & & $\checkmark$ & & & $\checkmark$ & & \\
\hline $\begin{array}{l}\text { İçöz ve Kozak } \\
\text { (1999) }\end{array}$ & 1979-1983 & $\begin{array}{l}\text { Turizm Issletmeciliği Dergisi'nde } \\
\text { yayınnanan makaleler }\end{array}$ & 93 makale & & & & & & & $\checkmark$ & & & & & & & & & & & & $\checkmark$ & $\checkmark$ & \\
\hline Kozak (2001b) & 1972-1998 & $\begin{array}{l}\text { Turizm pazarlaması ile ilgili } \\
\text { hazırlanan lisansüstü tez } \\
\text { çalış̧aları }\end{array}$ & 131 tez & $\boldsymbol{v}$ & $\boldsymbol{v}$ & & & $\boldsymbol{v}$ & & $\boldsymbol{v}$ & & & & & & & & & & & & & & \\
\hline $\begin{array}{l}\text { Çiçek ve Kozak } \\
\text { (2012a) }\end{array}$ & 1997-2011 & $\begin{array}{l}\text { Anatolia: Turizm Araştırmaları } \\
\text { Dergisi'nde yayınlanan makaleler }\end{array}$ & 202 makale & & $\checkmark$ & & & & $v$ & $\checkmark$ & $\checkmark$ & $\checkmark$ & $\checkmark$ & & & $\checkmark$ & & & & & $\checkmark$ & $\checkmark$ & $\checkmark$ & \\
\hline $\begin{array}{l}\text { Ciçek ve Kozak } \\
(2012 b)\end{array}$ & 1997-2010 & $\begin{array}{l}\text { Anatolia: Turizm Araştırmaları } \\
\text { Dergisi'nde yayınlanan makaleler }\end{array}$ & 192 makale & & $\checkmark$ & & & & $\checkmark$ & $\checkmark$ & $\checkmark$ & $\checkmark$ & $\checkmark$ & & & $\checkmark$ & & & & & $\checkmark$ & $\checkmark$ & $\checkmark$ & \\
\hline $\begin{array}{l}\text { Evren ve Kozak } \\
\text { (2012) }\end{array}$ & 2000-2010 & $\begin{array}{l}\text { Ulusal hakemli dergilerde turizm ile } \\
\text { ilgili yayınlanan makaleler }\end{array}$ & $\begin{array}{l}1217 \\
\text { makale }\end{array}$ & & $\checkmark$ & $\checkmark$ & & & $v$ & $\checkmark$ & $v$ & $\checkmark$ & & & & & & & & & $\checkmark$ & $\checkmark$ & $\checkmark$ & \\
\hline $\begin{array}{l}\text { Özel ve Kozak } \\
\text { (2012) }\end{array}$ & 2000-2011 & $\begin{array}{l}\text { Ulusal hakemli dergilerde turizm } \\
\text { pazarlaması ile ilgili yayınlanan } \\
\text { makaleler }\end{array}$ & 286 makale & & $\boldsymbol{v}$ & $\boldsymbol{v}$ & & & $\boldsymbol{v}$ & $\boldsymbol{v}$ & $\boldsymbol{v}$ & $\boldsymbol{v}$ & $\boldsymbol{v}$ & $\boldsymbol{v}$ & $\boldsymbol{v}$ & & & & & $\boldsymbol{v}$ & $\boldsymbol{v}$ & & $\boldsymbol{v}$ & \\
\hline $\begin{array}{l}\text { Türktarhan ve } \\
\text { Kozak (2012) }\end{array}$ & 1985-1994 & $\begin{array}{l}\text { Turizm Yillığ'nda yayınlanan } \\
\text { makaleler }\end{array}$ & 150 makale & & $\checkmark$ & & & & $v$ & $\checkmark$ & $\checkmark$ & $\checkmark$ & & & & & & & & & $\checkmark$ & $\checkmark$ & $\checkmark$ & $\checkmark$ \\
\hline $\begin{array}{l}\text { Yüncü ve Kozak } \\
\text { (2012) }\end{array}$ & 1997-2010 & $\begin{array}{l}\text { Anatolia: Turizm Araştırmaları } \\
\text { Dergisi'nde yayınlanan makaleler }\end{array}$ & 205 makale & & $\checkmark$ & & & & & $\checkmark$ & & & & & & & & & & $\checkmark$ & & & $\checkmark$ & \\
\hline $\begin{array}{l}\text { Zencir ve Kozak } \\
(2012)\end{array}$ & 2000-2010 & $\begin{array}{l}\text { Sosyal Bilimler Enstitü dergilerinde } \\
\text { turizm ile ilgili yayınlanan makaleler }\end{array}$ & 206 makale & & $\checkmark$ & $\checkmark$ & & & $\checkmark$ & $\checkmark$ & $v$ & $\checkmark$ & $v$ & & & & $\checkmark$ & & & & $\checkmark$ & & & \\
\hline $\begin{array}{l}\text { Çakııı, Yıldırım ve } \\
\text { Karacaoğlu (2013) }\end{array}$ & 2009-2012 & $\begin{array}{l}\text { Ulusal Turizm Kongresi'nde } \\
\text { sunulan bildiriler }\end{array}$ & 337 bildiri & & $\checkmark$ & & & & & $\checkmark$ & $\checkmark$ & $\checkmark$ & $\checkmark$ & & & c & & & & & $\boldsymbol{v}$ & $\boldsymbol{v}$ & $\checkmark$ & \\
\hline $\begin{array}{l}\text { Cevizkaya, Ilsay } \\
\text { ve Avcikurt (2014) }\end{array}$ & $2000-2013$ & $\begin{array}{l}\text { Turizm alanyazinında engelliler ile } \\
\text { ilgili yayınlanan çalısmalar } \\
\text { (makaleler ve tezler) }\end{array}$ & $\begin{array}{l}603 \text { tez } \\
49 \text { makale }\end{array}$ & $\boldsymbol{v}$ & $\boldsymbol{v}$ & $\boldsymbol{v}$ & & $\boldsymbol{v}$ & & $\boldsymbol{v}$ & & & & & & & & & & & & & & \\
\hline $\begin{array}{l}\text { Temizkan, Çiçek } \\
\text { ve Özdemir (2015) }\end{array}$ & $1991-2014$ & $\begin{array}{l}\text { Sağlik turizmi ile ilgili yayınlanan } \\
\text { makaleler (Türkçe ve Ingilizce) }\end{array}$ & 246 makale & & $\boldsymbol{v}$ & $\boldsymbol{v}$ & $v$ & & & $\boldsymbol{v}$ & $\boldsymbol{v}$ & & & & & & & & & & $\checkmark$ & & $\boldsymbol{v}$ & $\checkmark$ \\
\hline & & & & & & & & & & & & rgi ve & ülten i & e ilgili & aram & treler & & & & & & & & \\
\hline Kozak (1999) & & $\begin{array}{l}\text { Turizm, rekreasyon ile boş } \\
\text { zamanlar ve değerlendirilmesi } \\
\text { alanlarında akademik dergiler }\end{array}$ & 33 dergi & $\begin{array}{l}\text {-Gene } \\
\text { rekla } \\
\text {-Make } \\
\text {-YayII }\end{array}$ & & & . & & & & & & Il, dave & & & $\begin{array}{l}\text { yin sayı } \\
\text { blindre } \\
\text { anma d }\end{array}$ & & & & & rinın $\mathrm{k}$ & $\begin{array}{l}\text { Irşlanı } \\
\text { yayın } \\
\text { alması } \\
\end{array}$ & $\begin{array}{l}\text { Şekli, } \\
\text { ma süre }\end{array}$ & \\
\hline $\begin{array}{l}\begin{array}{l}\text { Özdemir ve Kozak } \\
(2000)\end{array} \\
\end{array}$ & 1983-1990 & T.C. Turizm Bankası A.Ş. Bülteni & 20 sayı & ülten & & & 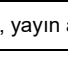 & ama & e poli & $\mathrm{sll,}$ & ginin & ümleri, & yayınla & an yaz & & & & & & & & & & \\
\hline
\end{tabular}


Araştırmacılar makalelerin yanı sıra lisansüstü tezler, bildiriler ve dergiler gibi diğer bilimsel yayınları da benzer parametreler çerçevesinde incelemektedir. Söz gelimi Kozak (2001b) turizm pazarlaması ile ilgili 1972-1998 yılları arasında yayınlanan lisansüstü tezleri tezlerin türü, hazırlandığı üniversite, tezlerin konusu ve hazırlandığı yıl parametreleri ile ele almaktadır. Tezlerin çoğunluğunun yüksek lisans düzeyinde yayınlandığı, en fazla tezin İstanbul Üniversitesi'nde yapıldığı, çoğunluğunun 19911995 yılları arasında basıldığı ve en çok pazarlama iletişimi alanında hazırlandığı tespit edilmiştir. Benzer bir şekilde Çakıcı ve arkadaşları (2013) Ulusal Turizm Kongrelerinde 2009-2012 yılları arasında sunulan 357 bildiriyi yazar, kurum, tür, atıf, özet, yöntem, geçerlilik ve güvenirlik ve analiz türleri açısından değerlendirmektedir. Bu bağlamda bildirilerin çoğunluğunun iki yazarlı olduğu, alan araştırması kullanıldığı, Türkçe kaynakların tercih edildiği ve birinci ve ikinci yazarların yardımcı doçent unvanına sahip olduğu sonucuna ulaşılmıştır. Diğer taraftan Kozak (1999) turizm, rekreasyon ve boş zamanlar değerlendirmesi alanlarında yayınlanan 33 akademik dergiyi genel bilgiler, makale denetim bilgileri ve yayın bilgileri doğrultusunda incelemektedir.

\section{Yöntem}

Çalışmada, 1978-2015 yılları arasında restoranlarda bahşiş ile ilgili uluslararası alanyazında yayınlanan makalelerin belirli parametreler çerçevesinde incelenmesi amaçlanmaktadır. Makaleler, bilimsel gelişmelerin izlenebilmesi ve değerlendirilebilmesi açısından önemli bir gösterge (Bayram, 1998) olduğundan dolayı bu çalışmada da sadece makalelerin değerlendirmeye alınması uygun görülmüştür. Bu bağlamda restoranlarda bahşiş ile ilgili makaleler çeşitli veri tabanları (EBSCO Host, JSTOR, SageJournal, Scopus, Springer Link, Wiley Online Library gibi) üzerinden taranmış ve 201 makaleye erişim sağlanmıştır. Çalışma kapsamında ulaşılan tüm makalelerin değerlendirmeye alınması uygun görülmüştür.

Restoranlarda bahşiş ile ilgili erişim sağlanan 201 makaleye ait tüm parametreler istatistiki bir programa aktarılmış ve bu program yardımıyla analizler gerçekleştirilmiştir. Çalışmada betimleyici istatistiki analizler kullanılmış ve ilgili parametreler frekans ve yüzde değerleri yardımı ile açıklanmaya çalışılmıştır. Makalelerin bibliyometrik profilinin belirlenebilmesi için kullanılan parametreler arasında makalenin yayınlandığı yıl, makalenin yayınlandığı dergi, makalenin yayınlandığı derginin yayın alanları, makalenin araştırma yaklaşımı, sayfa sayısı, atıf sayısı, makalenin veri toplama yöntemi, makalenin örneklem grubu, makalede verilerin toplandığı ülke ve şehir, yazar sayısı, yazarların isimleri, yazarların unvanları, yazarların çalıştığı kurumlar ve yazarların çalıştığı bölümler şeklinde sıralamak mümkündür. Çalışmada cevaplanmak istenen araştırma soruları aşağıdaki şekildedir.

- Makalelerin yayınlandığı yıllara göre dağılımı nedir?

- Makalelerin yayınlandığı dergilere göre dağılımı nedir?

- Dergilerin yayın alanlarına göre dağııımı nedir?

- Makalelerin araştırma yaklaşımlarına göre dağılımı nedir?

- Makalelerin konularına göre dağılımı nedir?

- Makalelerin sayfa sayısına göre dağılımı nedir?

- Makalelerin yapılan atıflara göre dağılımı nedir?

- Makalelerin veri toplama yöntemine göre dağılımı nedir?

- Makalelerin örneklem grubuna göre dağılımı nedir?

- Makalelerin verilerin toplandığı ülkelere ve şehirlere göre dağılımı nedir?

- Makalelerin verilerin toplandığı şehirlere göre dağılımı nedir?

- Makalelerin çok yazarlılık açısından durumu nedir? 
- Yazarların isimlerine göre dağılımı nedir?

- Yazarların unvanlarına göre dağılımı nedir?

- Yazarlarının çalışı̆̆ı kurumlara göre dağılımı nedir?

- Yazarlarının çalıştığı bölümlere göre dağııımı nedir?

\section{Bulgular}

1978-2015 yılları arasında restoranlarda bahşiş ile ilgili yayınlanan 201 makale çeşitli parametreler çerçevesinde incelenmiştir. İlgili yıllar arasında yayınlanan makalelere ait genel bilgilerden şu şekilde bahsetmek mümkündür. Makalelerin toplam sayfa sayısının 2395 ve ortalama sayfa sayısının da 11,9 olduğu görülmektedir. Yazar sayısının 378 ve makale başına ortalama yazar sayısının da 1,9 olduğu dikkat çekmektedir. Makalelerin toplam anahtar kelime sayısının 488 ve ortalama anahtar kelime sayısının da 2,4 olduğu tespit edilmiştir. Incelenen makaleler arasında 86 makalede ise anahtar kelime kullanılmadığı dikkat çekmektedir.

Makalelerin yayınlandığı yıllar incelendiğinde ulaşılabilen makaleler arasında restoranlarda bahşiş ile ilgili ilk makalenin 1978 yılında yayınlandığı tespit edilmiştir. Makalelerin yayınlandığı yıllara ilişkin veriler Tablo 2'de gösterilmektedir. Restoranlarda bahşiş ile ilgili en fazla çalışmanın yayınlandığı (15 makale) yılların 2003, 2013 ve 2014 yılları olduğu görülmektedir. Diğer taraftan 1979, 1982, 1983, 1985, 1987 ve 1991 yıllarında ise herhangi bir makalenin yayınlanmadığı dikkat çekmektedir. Tüm bunların ışığında özellikle 2000'li yıllardan sonra restoranlarda bahşiş ile ilgili yayınlanan makalelerin giderek artış gösterdiğini söylemek mümkündür. Makalelerin yayınlandığı yıllar üç farklı dönem şeklinde ele alındığında makalelerin \% 66,7'sinin 2004-2015 (III. Dönem), \% 27,9'unun 1991-2003 (II. Dönem) ve \% 5.4'ünün de 1978-1990 (I. Dönem) yılları arasında yayınlandığı sonucuna ulaşılmıştır.

Tablo 2: Makalelerin Yayınlandığı Yıllara Göre Dağılımı

\begin{tabular}{|c|c|c|c|c|c|}
\hline Yıllar & $\begin{array}{c}\text { Makale } \\
\text { Sayısı }\end{array}$ & Yıllar & $\begin{array}{c}\text { Makale } \\
\text { Sayısı }\end{array}$ & Yıllar & $\begin{array}{c}\text { Makale } \\
\text { Sayıs }\end{array}$ \\
\hline 1978 & 1 & 1991 & - & 2004 & 12 \\
\hline 1979 & - & 1992 & 2 & 2005 & 12 \\
\hline 1980 & 1 & 1993 & 3 & 2006 & 7 \\
\hline 1981 & 1 & 1994 & 1 & 2007 & 8 \\
\hline 1982 & - & 1995 & 1 & 2008 & 8 \\
\hline 1983 & - & 1996 & 2 & 2009 & 12 \\
\hline 1984 & 2 & 1997 & 3 & 2010 & 9 \\
\hline 1985 & - & 1998 & 5 & 2011 & 12 \\
\hline 1986 & 2 & 1999 & 4 & 2012 & 14 \\
\hline 1987 & - & 2000 & 5 & 2013 & 15 \\
\hline 1988 & 1 & 2001 & 7 & 2014 & 15 \\
\hline 1989 & 1 & 2002 & 8 & 2015 & 10 \\
\hline 1990 & 2 & 2003 & 15 & & $\mathbf{1 3 4}$ \\
\hline I.DönemToplam & $\mathbf{1 1}$ & II.DönemToplam & $\mathbf{5 6}$ & III.DönemToplam & $\mathbf{1 3}$ \\
\hline Genel Toplam & \multicolumn{2}{l}{}
\end{tabular}

Restoranlarda bahşiş ile ilgili yayınlanan 201 makalenin hangi dergilerde yayınlandığı incelenmiş ve makalelerin 83 farklı dergide yayınlandığı tespit edilmiştir. Tablo 3 incelendiğinde en fazla makale yayınlayan derginin 30 makale ile Journal of Applied Social Psychology olduğu görülmektedir. Ardından 27 makale ile International Journal of Hospitality Management dergisi gelmektedir. Üçüncü sırada ise 13 makale ile Cornell Hotel and Restaurant Administration Quarterly ve Journal of Foodservice Business Research dergisi yer almaktadır. Bu bağlamda restoranlarda bahşiş ile ilgili makalelerin \% 26,4'ünün ikinci ve üçüncü sırada yer alan turizm ve yiyecek-içecek ile 
ilgili dergilerde yayınlandığı dikkat çekmektedir. Dergilerin \% 31,2'sinin (63 dergi) de bu konu ile ilgili sadece 1 makale yayınladığı tespit edilmiştir.

Restoranlarda bahşiş ile ilgili makalelerin yayınlandığı dergilerin yayın alanlarına göre dağılımı da farklılık göstermektedir. Dergilerin yayın alanları incelendiğinde makalelerin \% 29,3'ünün turizm ile ilgili dergilerde yayınlandığı görülmektedir. Turizmin ardından makalelerin \% 18,9'unun sosyoloji, \% 13,9'unun ekonomi, \% 9'unun pazarlama, \% 7,4'ünün yiyecek ve içecek, \% 7'sinin işletme, \% 6'sının psikoloji, \% 1,5 'inin makalenin sosyal bilimler ve \% 7'sinin de diğer (hukuk, matematik, muhasebe, tarih gibi) ile ilgili dergilerde yayınlandığı dikkat çekmektedir.

Tablo 3: Makalelerin Yayınlandığı Dergilere Göre Dağılımı

\begin{tabular}{|l|c|c|}
\hline Dergi Adı & Makale Sayısı & $\%$ \\
\hline Journal of Applied Social Psychology & 30 & 14,9 \\
\hline International Journal of Hospitality Management & 27 & 13,4 \\
\hline Cornell Hotel and Restaurant Administration Quarterly & 13 & 6,5 \\
\hline Journal of Foodservice Business Research & 13 & 6,5 \\
\hline Journal of Economic Psychology & 7 & 3,5 \\
\hline The Journal of Socio-economics & 7 & 3,5 \\
\hline Journal of Hospitality and Tourism Research & 6 & 3,0 \\
\hline Journal of Services Marketing & 5 & 2,5 \\
\hline Applied Economics Letters & 4 & 2,0 \\
\hline Applied Economics & 3 & 1,5 \\
\hline Journal of Consumer Research & 3 & 1,5 \\
\hline Journal of Economic Behaviour and Organization & 3 & 1,5 \\
\hline The Social Science Journal & 3 & 1,5 \\
\hline Asia Pacific Journal of Tourism Reseacrh & 2 & 1,0 \\
\hline International Journal of Contemporary Hospitality Management & 2 & 1,0 \\
\hline Journal of Labor Research & 2 & 1,0 \\
\hline Psychological Reports & 2 & 1,0 \\
\hline Southern Economic Journal & 2 & 1,0 \\
\hline The Service Industries Journal & 2 & 1,0 \\
\hline The Sociological Quarterly & 2 & 1,0 \\
\hline Diğer & 63 & 31,2 \\
\hline Toplam & 201 & 100 \\
\hline
\end{tabular}

Makalelerin araştırma yaklaşımı diğer bir ifade ile görgül ya da kavramsal olması, ilgili alanda yapılan bilimsel çalışmaların düzeyi hakkında somut sonuçlar vermekte ve yapılan çalışma hakkında bilgi sahibi olunmasına yardımcı olmaktadır. (Kozak, 1994). İlgili yıllar arasında yayınlanan 201 makalenin \% 21,4'ünde (44 makale) kavramsal yaklaşım benimsenmiştir. Makalelerde tercih edilen araştırma yaklaşımlarının yıllara göre dağılımı Şekil 1'de gösterilmektedir. Bu bağlamda 2000 yılına kadar yayınlanan makalerde kavramsal yaklaşımın benimsendiği; 2001 yılından sonra yayınlanan makalelerde ise görgül araştırma yaklaşımının daha çok tercih ediildiği ve yıllar itibariyle giderek artış gösterdiği dikkat çekmektedir. 
Şekil1: Makalelerin Araştırma Yaklaşımlarının Yıllara Göre Dağılımı

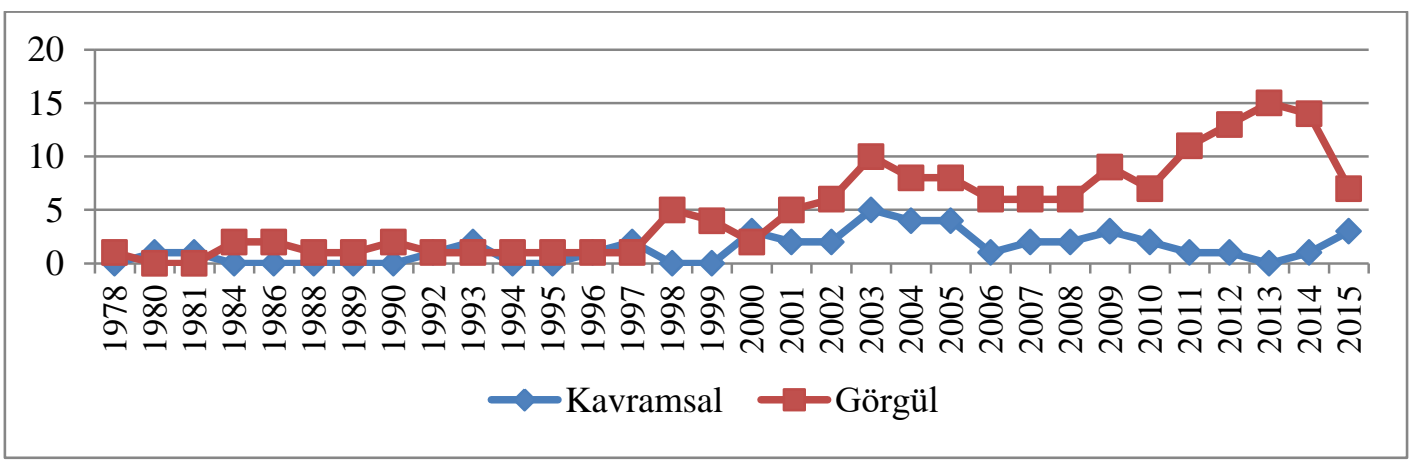

Makalelerin temel konuları ele alındığında çalışmaların 11 farklı konu çerçevesinde incelendiği görülmektedir. Makalelerin konularının dağılımı Tablo 4'te gösterilmekte ve toplamda en fazla makalenin bahşiş arttırma teknikleri ile ilgili yayınlandığı görülmektedir. İkinci sırada ise 27 makale ile hizmet kalitesi ile bahşiş ilişkisi özelinde yapılan çalışmalar gelmektedir. Bahşişin servis personeline sağladığı ekonomik katkılar (26 makale) ile ilgili yapılan makalelerin de üçüncü sırada geldiği dikkat çekmektedir. Makalelerin konularının araştırma yaklaşımına göre dağılımı incelendiğinde ise ekonomik etkiler, bahşiş uygulamaları ve gelenekleri ile genel bilgi konularında kavramsal çalışmaların daha fazla yapıldığı görülmektedir. Diğer konularda ise görgül araştırma yaklaşımı ile yapılan makalelerin sayısının daha fazla olduğu ön plana çıkmaktadır.

Tablo 4: Makalelerin Konularının Araştırma Yaklaşımına Göre Dağılımı

\begin{tabular}{|l|c|c|c|}
\hline \multirow{2}{*}{ Konu Adı } & \multicolumn{2}{|c|}{ Araştırma Yaklaşımı } & \multirow{2}{*}{ Toplam } \\
\cline { 2 - 3 } & Kavramsal & Görgül & \\
\hline Bahşiş arttırma teknikleri & 2 & 36 & 38 \\
\hline Hizmet kalitesi & 7 & 20 & 27 \\
\hline Ekonomik etkiler & 14 & 12 & 26 \\
\hline Bahşiş verme kararını/eğilimini etkileyen faktörler & 1 & 24 & 25 \\
\hline Motivasyon & 10 & 13 & 23 \\
\hline Etnik köken & 1 & 22 & 23 \\
\hline İnsan kaynakları & 1 & 14 & 15 \\
\hline Servis personelinin fiziksel çekiciliği & 0 & 9 & 9 \\
\hline Bahşş uygulamaları ve gelenekleri & 5 & 3 & 8 \\
\hline Genel bilgi & 3 & 1 & 4 \\
\hline Bahşşi tahmin etme unsurları & 0 & 3 & 3 \\
\hline Toplam & 44 & 157 & 201 \\
\hline
\end{tabular}

Çalışmada incelenen makalelerin sayfa sayısının en az 2, en fazla 37 ve ortalama 11,9 olduğu sonucuna ulaşılmıştır. Makalelerin sayfa sayısına göre dağılımı beş farklı grup altında incelenmektedir. Bu bağlamda toplamda 6-10 sayfa aralığında olan makalelerin sayısının $(\% 31,8)$ diğerlerine oranla daha fazla olduğu sonucuna ulaşıımıştır. Makalelerin \% 24,9'unun 11-15 sayfa aralığında ve \% 17,9'unun da 1-5 sayfa aralığında olduğu dikkat çekmektedir. Makalelerin sayfa sayılarının yıllara göre dağılımına bakıldığında ise I. Dönemde (1978-1990) 1-5 sayfa aralığındaki makalelerin sayısının daha fazla olduğu görülürken II. Dönem (1991-2003) ve III. Dönemde (20042015) ise 6-10 sayfa aralığındaki makalelerin sayısının diğerlerine oranla daha fazla olduğu görülmektedir. 
Tablo 5: Makalelerin Sayfa Sayılarının Yıllara Göre Dağılımı

\begin{tabular}{|l|c|c|c|c|c|c|c|c|}
\hline \multirow{2}{*}{ Sayfa Sayısı Aralığı } & \multicolumn{9}{|c|}{ Yıllar } & \multicolumn{2}{c|}{ Toplam } \\
\cline { 2 - 9 } & \multicolumn{1}{|c|}{$1978-1990$} & \multicolumn{2}{|c|}{$1991-2003$} & \multicolumn{2}{c|}{$2004-2015$} & \multicolumn{2}{c|}{} \\
\cline { 2 - 9 } & $\mathrm{n}$ & $\%$ & $\mathrm{n}$ & $\%$ & $\mathrm{n}$ & $\%$ & $\mathrm{n}$ & $\%$ \\
\hline $1-5$ & 6 & 54,5 & 12 & 21,5 & 18 & 13,5 & 36 & 17,9 \\
\hline $6-10$ & 2 & 18,2 & 20 & 35,7 & 42 & 31,3 & 64 & 31,8 \\
\hline $11-15$ & 2 & 18,2 & 13 & 23,2 & 35 & 26,1 & 50 & 24,9 \\
\hline $16-20$ & 0 & 0 & 6 & 10,7 & 22 & 16,4 & 28 & 13,9 \\
\hline 21 ve üzeri & 1 & 9,1 & 5 & 8,9 & 17 & 12,7 & 23 & 11,5 \\
\hline Toplam & 11 & 100 & 56 & 100 & 134 & 100 & 201 & 100 \\
\hline
\end{tabular}

Makalelerde yapılan atıflar sadece nicelik açısından değerlendirilmiş ve yapılan atıfların türleri incelenmiştir. Çalışmada incelenen 201 makalenin toplam atıf sayısının 5837 ve ortalama atıf sayısının da 29,1 (en az 1 ve en fazla 141) olduğu tespit edilmiştir. Atıf yapılan kaynakların türleri incelendiğinde toplam atıfların \% 72,9'unun makalelere, \% 16,4'ünün kitaplara, \% 9,7'sinin diğer kategorisinde yer alan kaynaklara yapıldığı görülmektedir. Bildirilere yapılan atıfların ise \% 0,9 oranında oldukça düşük olduğu dikkat çekmektedir. Bu bağlamda restoranlarda bahşiş konusunda makalelerin en fazla tercih edilen başvuru kaynağı olduğu, bildirilerin ise nadiren kullanıldığı söylenebilir. Diğer taraftan makalelerde yapılan atıf sayıları 4 farklı grup (1-20; 21-40; 41-60 ve 61 ve üzeri) altında incelenmektedir. Bu çerçevede 21-40 atıfı makalelerin sayısı ile 1-20 atıflı makalelerin sayısı arasında büyük bir fark olmadığı sonucuna ulaşıımıştır. İncelenen makalelerin \% 40,3'ünde (81 makale) 21-40 atıf yapılırken \% 39,8'inde (80 makale) de 1-20 atıf yapılmıştır. 29 makalede (\% 14,4) 41-60 atıf ve 11 makalede $(\% 5,5)$ ise 61 ve üzeri atıf kullanıımıştır.

Restoranlarda bahşiş ile ilgili yayınlanan makalelerde görgül araştırma yaklaşımının kullanıldığı 157 makalenin örneklem grubuna, veri toplama yöntemine, verilerin toplandığı ülke ve şehirlere göre dağılımı incelenmektedir. Makalelerin \% 65'inde (102 makale) örneklem grubu olarak müşterilerin seçildiği tespit edilmiştir. Makalelerin \% 21'inde (33 makale) de servis personelinin örneklem olarak seçildiği dikkat çekmektedir. Ardından örneklem grubu olarak öğrenci (8 makale), restoran yöneticisi (5 makale), turist (3 makale) ve diğerlerin (6 makale) geldiği sonucuna ulaşıımıştır. Diğer kategorisinde yer alan makalelerde ise birden fazla örneklem grubu (müşteri ve servis personeli, öğrenci ve servis personeli gibi) yer almaktadır. Veri toplama aracı incelendiğinde makalelerin \% 49,7'sinde (78 makale) anket tekniğinden yararlanıldığı dikkat çekmektedir. Diğer taraftan makalelerin \% 39,5'inde gözlem (62 makale), \% 7'sinde görüşme (11 makale) ve \% 3,8'inde diğer (6 makale) araçların kullanıldığı sonucuna ulaşılmıştır. Diğer taraftan ülkeler ve şehirler incelendiğinde ise yayınlanan makalelerin tamamında verilerin toplandığı ülkelerin belirtildiği görülmektedir. Bu bağlamda makale verilerinin toplandığı ülkeler arasında ilk sırada 108 çalışma (\% 68,8) ile Amerika gelmektedir. Amerika'yı 18 çalışma ile Fransa ve 8 çalışma ile İsrail takip etmektedir. Verilerin toplandığı şehirler arasında da 18 çalışma (\% 11,5) ile Fransa'da bulunan Vannes şehri ilk sırada gelmektedir. Vannes şehrini 7 çalışma ile Amerika'da bulunan Teksas eyaleti takip etmektedir. İncelenen 67 makalede ise verilerin toplandığı şehirlerin belirtilmediği sonucuna ulaşılmıştır. Verilerin toplandığı ülke ve şehirlere göre dağııımı Tablo 6'da gösterilmektedir.

İlgili yıllar arasında restoranlarda bahşiş ile ilgili yayınlanan makalelerin 378 yazar tarafından yazıldığı sonucuna ulaşılmıştır. Bu bağlamda makale başına ortalama 1,9 yazarın düştüğü tespit edilmiştir. Yazar sayısı ve çok yazarlılık durumu incelendiğinde tek yazarlı makalelerin sayısı ile iki yazarlı makalelerin sayısı arasında az bir fark olduğu görülmektedir. Bu çerçevede yayınlanan makalelerin 84'ünün tek 
yazarlı ve 79'unun da iki yazarlı olduğunu söylemek mümkündür. Ardından sırasıyla üç yazarlı (21 makale), dört yazarlı (13 makale), beş yazarlı (3 makale) ve altı yazarlı (1 makale) makaleler gelmektedir.

\section{Tablo 6: Makalelerin Verilerin Toplandığı Ülke ve Şehirlere Göre Dağılımı}

\begin{tabular}{|l|c|c|l|c|c|}
\hline Ülke Adı & $\mathbf{n}$ & $\%$ & Şehir Adı & $\mathbf{n}$ & $\%$ \\
\hline Amerika & 108 & 68,8 & Vannes (Fransa) & 18 & 11,5 \\
\hline Fransa & 18 & 11,5 & Teksas (Amerika) & 7 & 4,4 \\
\hline İsrail & 8 & 5,0 & Florida (Amerika) & 5 & 3,2 \\
\hline Hong Kong & 4 & 2,5 & New Jersey (Amerika) & 5 & 3,2 \\
\hline Güney Kore & 2 & 1,3 & New York (Amerika) & 5 & 3,2 \\
\hline İngiltere & 2 & 1,3 & Utah (Amerika) & 5 & 3,2 \\
\hline Türkiye & 2 & 1,3 & Detroit (Amerika) & 4 & 2,5 \\
\hline Diğer & 13 & 8,3 & Virginia (Amerika) & 4 & 2,5 \\
\hline Toplam & 157 & 100 & Hong Kong adası (Hong Kong) & 3 & 1,9 \\
\hline & & & Minnesota (Amerika) & 3 & 1,9 \\
\hline & & Tel Aviv (İsrail) & 3 & 1,9 \\
\hline & & Washington (Amerika) & 3 & 1,9 \\
\hline & & Diğer & 25 & 16 \\
\hline & & Belirtilmeyen & 67 & 42,7 \\
\hline & & Toplam & 157 & 100 \\
\hline
\end{tabular}

*Verilerin toplandığı ülkelerde sayısı 2 ve üzeri; şehirlerde ise 3 ve üzeri olanlar dikkate alınmıştır

Araştırma deneyimi fazla olmayan araştırmacıların daha deneyimli araştırmacılarla işbirliği içinde olması ve bu durumun araştırmacıların gelecekte yapacakları çalışmalara önemli katkılar sağlaması makalelerde çok yazarlılık durumu açısından önem arz etmektedir (Al, 2008). Benzer bir şekilde Evren ve Kozak (2012) da çok yazarlı makalelerde yazarların farklı bakış açıları ve bilgi birikimlerinin makalelerin niteliğine önemli katkılar sağladığını belirtmektedir. Bu bağlamda bu çalışmada da ilgili yıllar arasında yayınlanan restoranlarda bahşiş ile ilgili makalelerin çok yazarlılık durumu incelendiğinde makalelerin \% 58.2'sinin (117 makale) iki ve daha fazla yazar tarafından yazıldığı dikkat çekmektedir. Yazar sayılarının yıllara göre dağılımı Şekil 2'de gösterilmektedir. Makalelerin yazar sayılarının yıllara göre dağılımına bakıldığında ise tüm yazar kategorilerinde III. Dönemde yayınlanan makalelerin sayısının diğerlerine oranla daha fazla olduğu sonucuna varılmıştır.

Şekil 2: Makalelerin Yazar Sayılarının Yıllara Göre Dağılımı

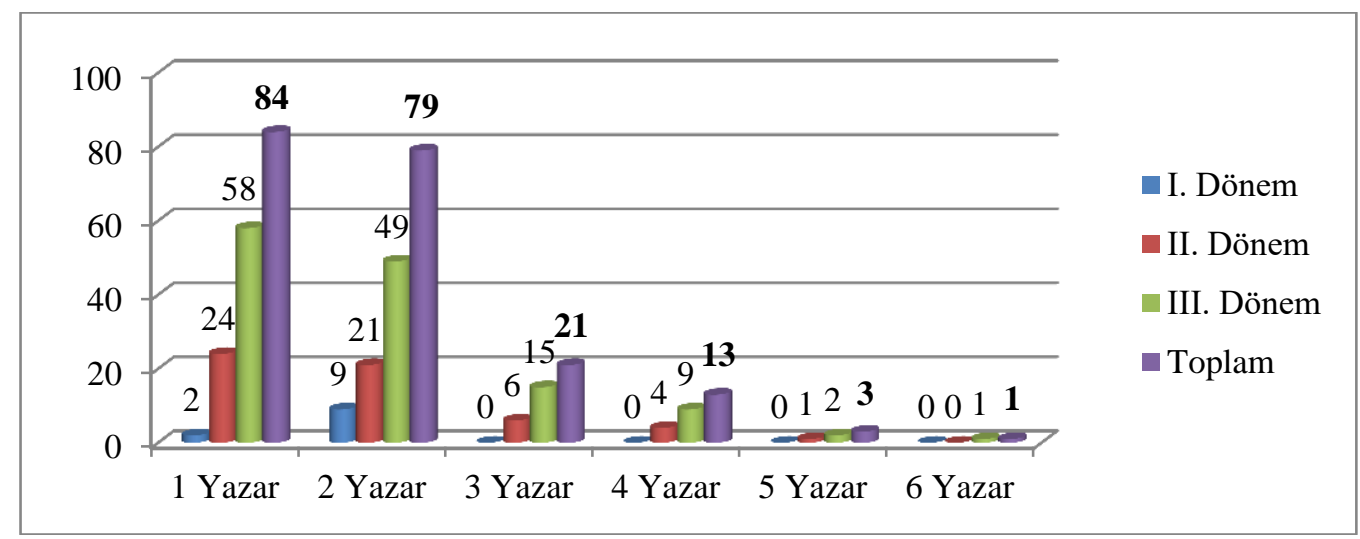

Makalelerin hangi yazarlar tarafından yazıldığı ve makale yazarlarının unvanları (prof., doç., yrd.doç., dr., arş. gör., öğr. gör., öğrenci) incelenmiştir. Bu bağlamda makalelere en fazla katkı sağlayan yazarın 54 makale ile Michael Lynn olduğu 
sonucuna ulaşılmıştır. Ardından Nicolas Gueguen (18 makale), Celine Jacob (14 makale) ve Ofer $\mathrm{H}$. Azar (14 makale) gelmektedir. Diğer taraftan yayınlanan makalelere 7 yazarın 3 defa, 24 yazarın 2 defa ve 164 yazarın da 1 defa katkı sağladığı dikkat çekmektedir. Makale yazarlarının unvanları incelendiğinde makalelerde 256 yazarın unvanının belirtilmediği görülmektedir. Bu çerçevede en fazla makale yayınlayan yazarların Doçent Doktor unvanına sahip olduğu görülürken, en az makale yayınlayan yazarların ise Araştırma Görevlisi unvanına sahip olduğu görülmektedir.

Tablo 7: Yazarların İsimleri ve Unvanlarına Göre Dağılımı

\begin{tabular}{|l|r|r|l|r|r|}
\hline Yazar Adı & $\mathbf{n}$ & $\%$ & Yazarların Unvanı & $\mathbf{n}$ & $\%$ \\
\hline Lynn, Michael & 54 & 14,3 & Doçent Doktor & 45 & 11,9 \\
\hline Gueguen, Nicolas & 18 & 4,8 & Profesör Doktor & 34 & 9,0 \\
\hline Jacob, Celine & 14 & 3,7 & Yardımcı Doçent Doktor & 19 & 5,0 \\
\hline Azar, Ofer H. & 14 & 3,7 & Öğrenci & 15 & 4,0 \\
\hline Brewster, Zachary W. & 10 & 2,6 & Doktor & 4 & 1,0 \\
\hline Bodvarsson, Örn B. & 7 & 1,8 & Öğretim Görevlisi & 3 & 0,8 \\
\hline Rind, Bruce & 5 & 1,3 & Araştırma Görevlisi & 2 & 0,5 \\
\hline Seiter, John S. & 5 & 1,3 & Belirtilmeyen & 256 & 67,8 \\
\hline Strohmetz, David & 5 & 1,3 & Toplam & 378 & 100 \\
\hline Sturman, Michael & 5 & 1,3 & & & \\
\hline Gibson, William A. & 4 & 1,1 & & & \\
\hline Parrett, Matt & 4 & 1,1 & & & \\
\hline Diğer & 233 & 61,7 & & & \\
\hline Toplam & 378 & 100 & & & \\
\hline
\end{tabular}

*Yazarların isimlerinde sayısı 4 ve üzerinde olanlar dikkate alınmıştır

Makale yazarlarının hangi kurumlarda ve bölümlerde çalıştığı makalelerde belirtilen adres bilgileri çerçevesinde incelenmiş ve sonuçlar Tablo 8'de gösterilmiştir. İlgili yıllar arasında restoranlarda bahşiş ile ilgili makalelerin 120 farklı kurumda çalışan yazarlar tarafından yayınlandığı sonucuna ulaşıımıştır. En fazla makalenin Cornell Üniversitesi'nde görev yapan akademisyenler tarafından yayınlandığı görülmektedir. Ardından South Brittany Üniversitesi (35 yazar) ve Negev Ben-Gurion Üniversitesi (18 yazar) gelmektedir.Makalelerin \% 31.2'sinin ilk üç sırada yer alan üniversitelerde çalışan yazarlar tarafından yayınlandığı dikkat çekmektedir.

Tablo 8: Yazarların Çalıştığı Kurumlar ve Bölümlere Göre Dağılımı

\begin{tabular}{|l|r|r|l|r|r|}
\hline Kurum Adı & $\mathbf{n}$ & $\%$ & Bölüm Adı & $\mathbf{n}$ & $\%$ \\
\hline Cornell University & 65 & 17,2 & Pazarlama & 47 & 12,4 \\
\hline University of South Brittany & 35 & 9,2 & Konaklama Iş̧letmeciliği & 45 & 11,9 \\
\hline Ben-Gurion University of the Negev & 18 & 4,8 & İşletme & 39 & 10,3 \\
\hline Pennsylvania State University & 10 & 2,7 & Ekonomi & 35 & 9,2 \\
\hline University of Central Florida & 10 & 2,7 & Sosyoloji & 34 & 9,0 \\
\hline University of Houston & 10 & 2,7 & Psikoloji & 28 & 7,4 \\
\hline University of Washington & 9 & 2,4 & Yiyecek-lçecek İşletmeciliği & 12 & 3,2 \\
\hline North Carolina State University & 8 & 2,1 & Turizm ve Otel İşletmeciliği & 11 & 2,9 \\
\hline Utah State University & 7 & 1,8 & Otel ve Restoran işletmeciliği & 10 & 2,6 \\
\hline Wayne State University & 7 & 1,8 & Eğitim & 10 & 2,6 \\
\hline St. Cloud State University & 6 & 1,6 & İletişim & 10 & 2,6 \\
\hline University of Hawaii & 6 & 1,6 & Turizm İşletmeciliği & 7 & 1,9 \\
\hline University of Nebraska-Lincoln & 6 & 1,6 & Hukuk & 6 & 1,6 \\
\hline Diğer & 180 & 47,6 & Insan Kaynakları Yönetimi & 6 & 1,6 \\
\hline Belirtilmeyen & 1 & 0,2 & Diğer & 7 & 1,9 \\
\hline Toplam & 378 & 100 & Belirtilmeyen & 71 & 18,9 \\
\hline & & & Toplam & 378 & 100 \\
\hline
\end{tabular}

*Yazarların çalıştıkları kurum ve bölümlerde sayısı 6 ve üzerinde olanlar dikkate alınmıştır.

İlgili yıllar arasında restoranlarda bahşiş ile ilgili makalelere katkı sağlayan yazarların çalıştıkları bölümler incelendiğinde ise 18 farklı bölümde çalışan yazarların 
makalelere katkı sağladığı görülmektedir. Bu bağlamda 47 yazarın pazarlama bölümünde çalıştığı dikkat çekmektedir. Pazarlama bölümünü 45 yazar ile konaklama işletmeciliği ve 39 yazar ile işletme bölümü takip etmektedir. Yazarların \% 19.8'inin turizm ile ilgili bölümlerde ve \% 3.2'sinin de yiyecek ve içecek işletmeciliği bölümlerinde çalıştığı sonucuna ulaşılmıştır. Makalelerde 71 yazarın ise çalıştığı bölümün belirtilmediği görülmektedir.

\section{Tartışma ve Sonuç}

Çalışmada, 1978-2015 yılları arasında restoranlarda bahşiş ile ilgili uluslararası alanyazında yayınlanan makalelerin belirli parametreler çerçevesinde incelenmesi amaçlanmaktadır. Bu bağlamda çalışmada ilgili yıllar arasında yayınlanan ve çeşitli veri tabanları (EBSCO Host, JSTOR, Sage Journal, Scopus, Springer Link, Wiley Online Library gibi) üzerinden erişim sağlanan 201 makale inceleme kapsamına alınmıştır. Bu çalışma restoranlarda bahşiş ile ilgili alanyazının durumu, gelişim süreci ve sorunları hakkında değerlendirme ve yorumlama imkanı sunmaktadır. Restoranlarda bahşiş ile ilgili makalelerin sayısının 2010 yılından itibaren giderek artış gösterdiği tespit edilmiştir. Benzer bir şekilde Temizkan ve arkadaşları (2015) tarafından yapılan çalışmada da sağlık turizmi ile ilgili yayınlanan makalelerin 2011 yılından sonra artış göstermeye başladığı belirtilmektedir. Şahin ve Acun (2015) da son yıllarda turist rehberliği ile ilgili makalelerin sayısının arttığını dile getirmektedir. Bu bağlamda alanyazındaki çalışmalarda elde edilen bulgular bu çalışmanın sonuçlarını destekler niteliktedir. Bu durumun nedeni turizm alanında turizm işletmeciliği, gastronomi ve mutfak sanatları, turist rehberliği ve rekreasyon yönetimi gibi bölümleşmeye gidilmesi ve buna bağlı olarak bu alanlar ile ilgili yapılan yayınların sayısının artması olarak gösterilebilir. Makalelerin yayınlandığı dergiler arasında Journal of Applied Social Psychology Dergisi'nin ilk sırada geldiği görülmektedir. Restoranlarda bahşiş ile ilgili en fazla makale yayınlayan derginin sosyoloji kökenli olmasının temelinde bahşişin psikolojik ve sosyolojik bir olgu olması ve bu alanda çalışan araştırmacıların daha fazla bu konuya eğilim göstermesi yatmaktadır.

Makalelerin \% 78,6'sında görgül araştırma yaklaşımı benimsenmiştir. Benzer bir şekilde turizm alanyazınında yapılan araştırmalarda (Zencir ve Kozak, 2012; Türktarhan ve Kozak, 2012; Özel ve Kozak, 2012; Evren ve Kozak, 2012, Çiçek ve Kozak, 2012b; Temizkan vd., 2015) da görgül araştırma yaklaşımının daha çok benimsendiği sonucuna ulaşılmıştır. Bu bağlamda yayınlanan makalelerin kavramsal çalışmalardan ziyade görgül araştırmalar olduğu ön plana çıkmaktadır. 6-10 sayfa aralığında olan makalelerin sayısının diğerlerine oranla daha fazla olduğu sonucuna ulaşılmıştır. Çiçek ve Kozak'ın (2012b) çalışması da bu bulguları destekler niteliktedir. Diğer taraftan 21-40 arası atıf yapılan makalelerin sayısının daha fazla olduğu tespit edilmiştir. Turizm, gastronomi ve yiyecek-içecek işletmeciliği alanına özgü akademik dergilerin sayısının artmaya başlaması beraberinde bu alanlar ile ilgili başta makaleler olmak üzere birçok akademik çalışmanın ortaya çıkmasına neden olmuştur. Bu çalışmada da atıf yapılan kaynakların türlerine bakıldığında atıfların \% 72,9'unun makalelere yapıldığı dikkat çekmektedir. Bu bulgular Özel ve Kozak (2012) tarafından yapılan çalışmanın bulguları ile benzerlik göstermektedir. Yazar sayısı ve çok yazarlıık durumu ele alındığında 201 makalenin toplam 378 yazar tarafından yazıldığı sonucuna ulaşılmıştır. Makalelerin çoğunluğunun tek yazarlı olduğu dikkat çekmektedir. Bu bağlamda elde edilen bulgular daha önce yapılan çalışmaların bulguları (Evren ve Kozak, 2012; Türktarhan ve Kozak, 2012; Çiçek ve Kozak, 2012b; Temizkan vd., 2015) ile örtüşmektedir. Turizm, gastronomi ve yiyecek-içecek işletmeciliği alanının yapısı gereği, disiplinlerarası çalışmalardan ziyade bireysel çalışmaların daha fazla olması bu durumun nedenlerinden biri olarak gösterilebilir. Çalışmada veri toplama aracı olarak makalelerin \% 49,7'sinde anket tekniğinden 
yararlanıldığı sonucuna ulaşılmıştır. Aslında gastronomi ve yiyecek-içecek işletmeciliği alanında yapılan çalışmalarda anket tekniğinin daha fazla kullanıldığı ancak son dönemlerde ise görüşme ve gözlem gibi veri toplama araçlarına yönelik artış eğilimi olduğu söylenebilir. Örneklem grubuna bakıldığında ise makalelerin çoğunluğunda müşterilerin örneklem olarak seçildiği dikkat çekmektedir. Bu durumun temelinde müşterilerin en kolay ulaşılabilir örneklem grubu olması ve araştırmacılar açısından da zaman ve maliyet yükünün az olması gibi sebepler olduğu düşünülmektedir. Diğer taraftan verilerin toplandığı ülke bazında verilerin \% 68,8'inin Amerika'da toplandığı tespit edilmiştir. Aslında bu durum yazarların çoğunluğunun Amerika'da bulunan üniversitelerde çalışmasından kaynaklanmaktadır. Şehir bazında bakıldığında ise Fransa'da bulunan Vannes şehrinin ilk sırada geldiği ve 18 çalışmanın bu şehirde yapıldığı dikkat çekmektedir. Bu bağlamda en fazla çalışmanın bu şehirde yapılmasının temel sebebi de araştırmacıların çalıştığı üniversitenin o şehirde bulunması şeklinde açıklanabilir.

Çalışma hem araştırmacılara hem de ilgili yazına çeşitli katkılar sunmaktadır. Restoranlarda bahşiş konusunda çalışma yapacak araştırmacılar hangi konularda çalışma yapılabileceği hususunda bu çalışmadan fikir elde edebilir ve bu çerçevede çalışmalarını tasarlayabilir. Araştırmacılar restoranlarda bahşiş ile ilgili yayınlanan makalelerde hangi araştırma yöntemlerinin kullanıldığı, hangi veri toplama yöntemine başvurulduğu ve örneklem grubu olarak hangi kitlenin seçileceği ile ilgili detaylı bilgi alabilir. Diğer taraftan ulusal yazında turizm ile ilgili yapılmış bibliyometrik çalışmalara da hem çalışmada kullanılan parametreler hem de çalışma konusu çerçevesinde farklı bir bakış açısı getireceği ve çalışmanın restoranlar özelinde yapılan ilk bibliyometrik çalışma olması nedeniyle önem arz edeceği düşünülmektedir. Araştırmanın başlıca sınırılığını uluslararası alanyazında yayınlanan ve veri tabanları üzerinden erişimi sağlanan makalelerin incelenmesi oluşturmaktadır. Bu bağlamda ileriki araştırmalarda bu makalelerin yanı sıra ulaşılabilen diğer makaleler ile kitap, kitap bölümü ya da kongrelerde sunulan bildiriler inceleme kapsamına alınabilir ve araştırma tekrarlanabilir. Araştırmanın diğer bir sınırııı̆ını da çalışmada incelenen makalelerin restoranlarda bahşiş konusu ile sınırlı tutulması oluşturmaktadır. Bu bağlamda da ileride yapılacak çalışmalarda gerek restoranlar özelinde gerekse yiyecek ve içecek ile ilgili makaleler genelinde çalışma gerçekleştirilebilir.

\section{Kaynakça}

Al, U. (2008), Türkiye'nin Bilimsel Yayın Politikası: Atıf Dizinlerine Dayalı Bibliyometrik Bir Yaklaşım (Basılmamış Doktora Tezi).Ankara: Hacettepe Üniversitesi Sosyal Bilimler Enstitüsü.

Al, U. ve Coştur, R. (2007), 'Türk Psikoloji Dergisi'nin Bibliyometrik Profili' Türk Kütüphaneciliği, 21(2), ss.142-163.

Al, U. ve Soydal, İ. (2012), 'Dergi Kendine Atıfının Etkisi: Energy Education Science and Technology Örneği' Türk Kütüphaneciliği, 26(4), ss.699-714.

Al, U.ve Tonta, Y. (2004), 'Atıf Analizi: Hacettepe Üniversitesi Kütüphanecilik Bölümü Tezlerinde Atıf Yapılan Kaynaklar' Bilgi Dünyası, 5(1), ss.19-47.

Bayram, Ö. G. (1998), 'Atıf Verisi (Citation Data) ve Enformetrik Yasalar: Türk Kütüphanecilik Literatüründeki Doktora Tezleri Üzerinde Bir Uygulama' Türk Kütüphaneciliği, 12(1), ss.142-163.

Cevizkaya, G., İlsay, S. ve Avcıkurt, C. (2014), 'Turizm Alan Yazınında Engelliler ile ilgili Çalışmaların Bibliyometrik Profili' Gazi Üniversitesi Turizm Fakültesi Dergisi, 2, ss.101-108.

Çakıcı, A. C., Yıldııım, O. ve Karacaoğlu, S. (2013), 'Ulusal Turizm Kongreleri Bildirilerinin Bibliyometrik Profili, 14.Ulusal Turizm Kongresi, Kayseri: Erciyes Üniversitesi Turizm Fakültesi, ss. 1429-1447. 
Çiçek, D. ve Kozak, N. (2012a), 'Anatolia: Turizm Araştırmaları Dergisi'nde Yayınlanan Hakem Denetimli Makalelerin Bibliyometrik Profili' Türk Kütüphaneciliği. 26(4), ss.734-756.

Çiçek, D., ve Kozak, N. (2012b), 'Anatolia: Turizm Araştırmaları Dergisi'nde Yayınlanan Hakem Denetimli Makalelerin Bibliyometrik Profili, VI. Lisansüstü Turizm Öğrencileri Araştırma Kongresi, Antalya: Anatolia Turizm Araştırmaları Dergisi ve Gazi Üniversitesi, ss. 196-211.

Diodato, V. P. (1994), Dictionary of Bibliometrics, Portland: The Hawthorne Press.

Evren, S. ve Kozak, N. (2012), Türkiye'de 2000-2010 Yılları Arasında Yayınlanan Turizm Konulu Makalelerin Bibliyometrik Analizi, VI. Lisansüstü Turizm Öğrencileri Araştırma Kongresi, Antalya: Anatolia: Turizm Araştırmaları Dergisi ve Gazi Üniversitesi, ss.250-266.

Hall, C. M. (2011), 'Publish or Perish? Bibliometric Analysis, Journal Ranking and The Assesment of Research Quality in Tourism' Tourism Management, 32(1), ss.1627.

Huang, S. S. ve Hsu, C. H. (2008), 'Recent Tourism and Hospitality Research in China' International Journal of Hospitality \& Tourism Administration, 9(3), ss.267-287.

İçöz, O. ve Kozak, N. (1999), 'Turizm İşletmeciliği Dergisi'nin Turizm Literatürüne Katkısı Hakkında Bir Inceleme' Anatolia: Turizm Araştırmaları Dergisi, 10(2), ss.9-17.

İnönü, E. (1971). 1923-1966 Döneminde Fizik Dalındaki Araştırmalara Türkiye'nin Katkısını Gösteren Bir Bibliyografya ve Bazı Gözlemler. Ankara: ODTÜ FenEdebiyat Fakültesi Yayınları - Yayın No:24.

Jogaratnam, G., McCleary, K. W., Mena, M. M.ve Yoo, J. J. (2005), 'An Analysis of Hospitality and Tourism Research: Institutional Contributions' Journal of Hospitality \& Tourism Research. 29(3), ss.356-371.

Kozak, N. (1994) 'Anatolia Dergisi'nde Yayınlanan Yazılar Üzerine Bir İnceleme' Anatolia Turizm Araştırmaları Dergisi, 5(3), ss.22-33.

Kozak, N. (1995), 'Türkiye'de Yayınlanan Turizm Konulu Makaleler Üzerine Bir İnceleme' Anatolia: Turizm Araştırmaları Dergisi, 6(1), ss.62-72.

Kozak, N. (1999), 'Dünya Genelinde "Turizm”, "Rekreasyon” ve "Boş Zamanlar ve Değerlendirilmesi" Alanlarında Yayınlanmakta Olan Akademik Dergiler Üzerinde Bir Araştırma' Türk Kütüphaneciliği, 13(1), ss.5-27.

Kozak, N. (2001a), 'Sağlık, Sosyal ve Teknik Bilimleri Alanlarında Yayınlanmakta Olan Akademik Dergiler Üzerine Karşılaştırmalı Bir İnceleme' Türk Kütüphaneciliği, 15(3), ss.296-310.

Kozak, N. (2001b), 'Türkiye'de Turizm Pazarlaması Literatürünün Gelişim Süreci: 1972-1999 Yılları Arasında Hazırlanmış Lisansüstü Tez Çalışmaları Üzerine Biyo-Bibliyografik Bir Inceleme' Anatolia: Turizm Araştırmaları Dergisi, 12(1), ss.26-33

Kozak, N. (2003), 'Türkiye'de Yayınlanan Akademik Dergilerin Niteliklerindeki Zaman İçerisindeki Değişim Nedenleri: Sağlık, Sosyal ve Teknik Bilim Alanlarında Yayınlanan Dergiler Üzerine Bir İnceleme' Bilgi Dünyası, 4(2), ss.152-153.

Law, R. ve Cheung, P. (2008), 'An Analysis of Publications in Leading Tourism Journals and Its Implications' Journal of China Tourism Research, 4(1), ss.7897.

Ma, J. ve Law, R. (2009), 'Components of Tourism Research: Evidence from Annals of Tourism Research' An International Journal of Tourism and Hospitality Research, 20(1), ss. 62-74.

McKercher, B. (2007), 'A Study of Prolific Authors in 25 Tourism and Hospitality Journals' Journal of Hospitality \& Tourism Education, 19(2), ss.23-30.

McKercher, B. (2008), 'A Citation Analysis of Tourism Scholars' Tourism Management, 29 (6), ss.1226-1232. 
Özdemir, M. ve Kozak, N. (2000), 'Türkiye Turizm Yayıncılığı Tarihinen Bir Süreli Yayın: T.C. Turizm Bankası A.Ş. Bülteni' Anatolia: Turizm Araştırmaları Dergisi, 11(2), ss.129-141.

Özel, Ç. H. ve Kozak, N. (2012), 'Turizm Pazarlaması Alanının Bibliyometrik Profili (2000-2010) ve Bir Atıf Analizi Çalışması' Türk Kütüphaneciliği, 26(4), ss.715733.

Özinönü, A. K. (1970). Growth in Turkish Positive Basic Sciences: 1933-1966. Ankara: Middle East Technical University .

Palmer, A. L., Sese, A. ve Montano, J. J. (2005), 'Tourism and Statistics: Bibliometric Study 1998-2002' Annals of Tourism Research, 32(1), ss.167-178.

Pritchard, A. (1969), 'Statistical Bibliography or Bibliometrics?' Journal of Documentation, 25, ss.348-349.

Ryan, C. (2005), 'The Ranking and Rating of Academics and Journals in Tourism Research' Tourism Management, 26, ss.657-662.

Sanchez, A. D., Garcia, J. A., Rama, M. C. ve Vazquez, E. G. (2016), Literature Review of Wine Tourism Research: Bibliometric Analysis (1984-2014). İçinde M. Peris-Ortiz, M. C. Rama ve C. Rueda-Armengot (Editörler), Wine and Tourism: A Strategic Segment for Sustainable Economic Development, İsviçre: Springer International Publishing, ss. 257-273.

Şakar, G. D.ve Cerit, A. G. (2013), 'Uluslararası Alan İndekslerinde Türkiye Pazarlama Yazını: Bibliyometrik Analizler ve Nitel Bir Araştırma' Atatürk Üniversitesi Íktisadi ve Idari Bilimler Dergisi, 27(4), ss.37-62.

Temizkan, S. P., Çiçek, D. ve Özdemir, C. (2015), 'Sağıık Turizmi Konusunda Yayınlanan Makalelelerin Bibliyometrik Profili' International Journal of Human Sciences, 12(2), ss.394-415.

Türktarhan, G.ve Kozak, N. (2012), Turizm Yıllığı'nın Bibliyometrik Profili, VI. Lisansüstü Turizm Öğrencileri Araştırma Kongresi, Antalya: Anatolia: Turizm Araştırmaları Dergisi ve Gazi Üniversitesi, ss. 567-584.

Ulu, S. ve Akdağ, M. (2015), 'Dergilerde Yayınlanan Hakem Denetimli Makalelerin Bibliyometrik Profili: Selçuk İletişim Örneği' Selçuk Iletişim, 9(1), ss.5-21.

Üstdiken, B.ve Pasadeos, Y. (1992), 'Türkiye'de Yayınlanan Yönteimle İlgili Makalelerdeki Atıflar Üzerine Bir İnceleme' Amme Ídaresi Dergisi, 25(2), ss.107134

Üstdiken, B. ve Pasadeos, Y. (1993), 'Türkiye'de Örgütler ve Yönetim Yazını' Amme Idaresi Dergisi, 26(2), ss.73-93.

Webster, J. ve Watson, R. T. (2002), 'Analyzing the Past to Prepare for the Future: Writing A Literature Review' MIS Quarterly, 26(2), ss.13-23.

Yalçın, H. (2010), 'Millî Folklor Dergisi'nin Bibliyometrik Profili (2007-2009), Millî Folklor, 85, ss.205-211.

Yozgat, U. ve Kartaltepe, N. (2009), 'Ulusal Yönteim ve Organizasyon Kongre Kitaplarında Yer Alan Bildirilerin Bibiyometrik Profili: Örgüt Teorisi ve Örgütsel Davranış Bildirileri Üzerine Bir Araştırma' Eskişehir Osmangazi Üniversitesi IïBF Dergisi, 4(1), ss.149-165.

Yüncü, D. K. ve Kozak, N. (2012), 'Anatolia Turizm Araştırmaları Dergisi'nin Bibliyometrik Analizi: Araştırma Konuları ve Kurumlar Arası İşbirliğinin Sosyal Ağ Analiz ile İncelenmesi' VI. Lisansüstü Turizm Öğrencileri Araştırma Kongresi, Antalya: Anatolia: Turizm Araştırmaları Dergisi ve Gazi Üniversitesi, ss. 642-660.

Zencir, E. ve Kozak, N. (2012), 'Sosyal Bilimler Enstitü Dergilerinde Yayınlanan Turizm Makalelerinin Bibliyometrik Profili (2000-2010)' VI. Lisansüstü Turizm Öğrencileri Araştırma Kongresi, Antalya: Anatolia: Turizm Araştırmaları Dergisi ve Gazi Üniversitesi, ss. 673-682. 